ReVISTA de BIOLOGía TROPICAL

\title{
Population status of the tree Sacoglottis holdridgei (Humiriaceae) at Isla del Coco National Park, Costa Rica
}

\author{
Luis Guillermo Acosta-Vargas \\ Instituto Tecnológico de Costa Rica, Escuela de Ingeniería Forestal, Apartado 159-7050, Cartago, Costa Rica; \\ lacosta@itcr.ac.cr, acosta.luisguillermo@gmail.com
}

Received 17-VIII-2014. C Corrected 03-IX-2015. Accepted 07-IX-2015.

\begin{abstract}
Isla del Coco is the only oceanic island in the Eastern Pacific with humid tropical climate. Its forests have a particular structure with a unique array of plant species and high endemism. There are few studies on the flora or forest monitoring on the island. The population structure of Sacoglottis holdridgei was analyzed using data from six years with data points taken in 2006 and 2012, including sampling of regeneration in 2012. Sacoglottis holdridgei was the most important tree species, presenting in 2012 the highest Importance Value Index $(190.7 \pm 21.8)$, abundance $\left(158.5 \pm 40.3 \mathrm{Nha}^{-1}\right.$ or $39.5 \%$ of the forest $)$ and basal area $\left(15.6 \mathrm{~m}^{2} \mathrm{ha}^{-1}\right.$ or 72.9 $\%$ of the forest). It was present in all three height strata with dominance in the highest. Annual mortality was reported at $3.3 \%$ and recruitment at $1.2 \%$. The diameter distribution of forest fits the inverted $J$ model, but not for the reported species of which only $S$. holdridgei tends to adjust for $\mathrm{DBH}>40 \mathrm{~cm}$. Regeneration fitted the inverted $J$ model with values below those reported for continental forests. Even though it was the dominant species, $S$. holdridgei showed low regeneration values. This particular condition, give way hypotheses related to the introduction of species, species biology and climate change which could influence the future development of S. holdridgei and forests of Isla del Coco. Rev. Biol. Trop. 64 (Suppl. 1): S263-S275. Epub 2016 Febrary 01.
\end{abstract}

Key words: Isla del Coco, Sacoglottis holdridgei, regeneration, population, climate change, mortality, recruitment, Cocos Island.

Isla del Coco (Cocos Island) is an oceanic island located in the Eastern Tropical Pacific that belongs to Costa Rica. Isla del Coco was declared a National Park in 1978 (Executive Decree No. 08748-A) and it is considered globally significant for its natural richness. In 1997 it was declared a World Heritage Site by UNESCO (United Nations Educational, Scientific and Cultural Organization) and in 1998 was declared a wetland of international importance within the RAMSAR Convention (Convention on Wetlands of International Importance especially as Waterfowl Habitat) (Trusty, Kesler, \& Delgado, 2006).

Isla del Coco has been scarcely deforested. Most deforestation occurred in the inhabited parts of the island around Wafer and Chatham Bays. Another impact on its native vegetation has been the introduction of animals, accidentally or not (Trusty et al., 2006). One of the biggest quantifiable impacts due to the introduction of species, is the removal of soil and its consequent high rates of erosion caused by feral pigs (Sierra, 2001). Changes in forest cover due to fallen trees and landslides are observed nowadays.

Impacts on ecosystems, native flora and fauna of islands, as a result of actions made by humans including species introduction have been extensively studied (Green, O'Dowd, \& Lake, 1997; Donlan et al., 2000; O’Dowd, Green, \& Lake, 2003; Smith-Ramírez et al., 2013). However, the effects of species introduction on Isla del Coco are poorly investigated. Nowadays, actions on research focused on understanding impacts on native species will play an important milestone on conservation of terrestrial ecosystems on Isla del Coco. 
The oceanic origin of Isla del Coco has been of great interest, attracting scientists that published a large number of investigations (Cortés, 2008; 2012). However, these studies mostly cover aspects related to marine biology, marine geology, oceanography, atmospheric and social science (Cortés, 2008). Studies on the flora have been few, see for example: Fosberg \& Klawe (1966), Trusty et al. (2006), Bogarín, Warner, Powell \& Savolainen (2011) and Trusty et al. (2012). Trusty et al. (2006) recorded 263 plant species, of which 37 are endemic.

The most common woody species on Isla del Coco is Sacoglottis holdridgei Cuatrec., 1964. It is present in most of the plant associations described by Trusty et al. (2006). In the low elevation humid forest (LEHF), it shares the canopy with Clusia rosea, Ocotea insularis, Henriettella fascicularis and Miconia dodecandra, while for the high elevation cloud forest (HECF) the canopy is exclusive for $S$. holdridgei (Trusty et al., 2006; Porras-Jiménez,
Acosta-Vargas, Castillo-Ugalde, \& QuesadaMonge, 2014). Sacoglottis holdridgei (Fig. 1A-D) belongs to the Family Humiriaceae. Most of the species of the family occur in the Neotropics, with only one species on the west coast of Africa (Cuatrecasas, 1961; 1964). In Costa Rica, in addition to S. holdridgei, there are five species in the family found only in continental lands: Humiriastrum diguense, Vantanea barbourii, Vantanea occidentalis, Sacoglottis trichogyna, and Sacoglottis sp. A (Zamora, 2007).

Although there are studies describing the vegetation of Isla del Coco (Rivera, 2006; Zamora, 2008; Trusty et al., 2006; Porras-Jiménez, 2012), no studies have been conducted to characterize and describe the current status of the flora populations and the impacts that they may be facing by introduced species or natural processes. It is for this reason the interest to describe the status of the population of $S$. holdridgei, which is the dominant tree species since it has been observed that its population
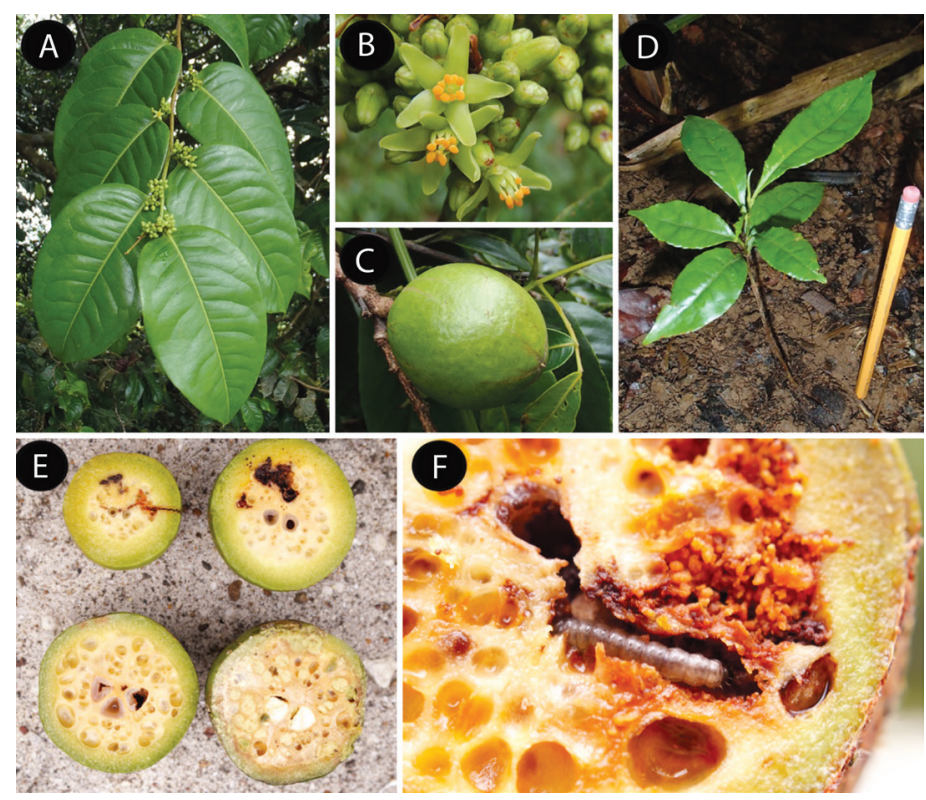

Fig. 1. S. holdridgei. A. Foliage; B. Flowers; C. Fruits; D. Young plant; E. Fruits in ripening stages; F. Effects caused by microlepidoptera larvae. 
is largely mature and with poor regeneration; situation posed to future changes in forest structure and diversity.

\section{MATERIALS AND METHODS}

Study site: Isla del Coco is located $500 \mathrm{~km}$ south-southwest of mainland Costa Rica $\left(5^{\circ} 30^{\prime}-5^{\circ} 34^{\prime} \mathrm{N}-87^{\circ} 01^{\prime}-87^{\circ} 06^{\prime} \mathrm{W}\right)$ in the Eastern Tropical Pacific (Fig. 2) (Cortés, 2008). It is the only emerged point of the Isla del Coco Volcanic Ridge, made up of mountains and submarine volcanoes, which extends $1200 \mathrm{~km}$ from Galapagos Islands, Ecuador until facing the Pacific coast in southeastern Costa Rica, in the Middle America Trench (Rojas, \& Alvarado, 2012).

Isla del Coco and the surrounding islets are the summit of the seamount that rises about $1000 \mathrm{~m}$ from the crest of Coco Volcanic Cordillera. Processes of erosion have reduced its size. The island has roughly a rectangular shape, most of its banks are comprised of almost vertical cliffs. On the southwest side is the highest point, Cerro Yglesias, 575 m.a.s.l., and to northeast the highest point reaches 300 m.a.s.l., and consists of more gentle slopes than in the southwest side (Castillo et al., 1988). Its origin is volcanic, comprising accumulated lava flows, dikes and pyroclastic rocks, of about 2 million years old. The rocks are of alkaline composition (Malavassi, 1983; Castillo et al., 1988).

Isla del Coco is the only oceanic island in the Southeast Pacific with humid tropical climate. Climate and seasonality of Isla del Coco is the result of its location within the Intertropical Convergence Zone and the influence of the warm waters of the North Equatorial Countercurrent. The island is an extremely rainy place. It receives an average annual rainfall of $7000 \mathrm{~mm}$ and it is almost permanently under great cloudiness. It is covered by evergreen wet forest but it also has an area of cloud forest, an exceptional feature among the islands at this latitude. (Bolívar, Rovinski, \& Ching, 2000). The annual average temperature is $25.5^{\circ} \mathrm{C}$, with a minimal of $23.1^{\circ} \mathrm{C}$ and maximum of $27.6^{\circ} \mathrm{C}$. Annual rainfall ranges from $5000-7000 \mathrm{~mm}$ (Herrera, 1986).

Establishment of permanent sample plots: Rivera (2006) established eight permanent sample plots (PSP) of 50x50 m $\left(2500 \mathrm{~m}^{2}\right)$ subdivided into grids of $10 \times 10 \mathrm{~m}$. The PSP were located in the plant association of low elevation humid forest (LEHF) described by

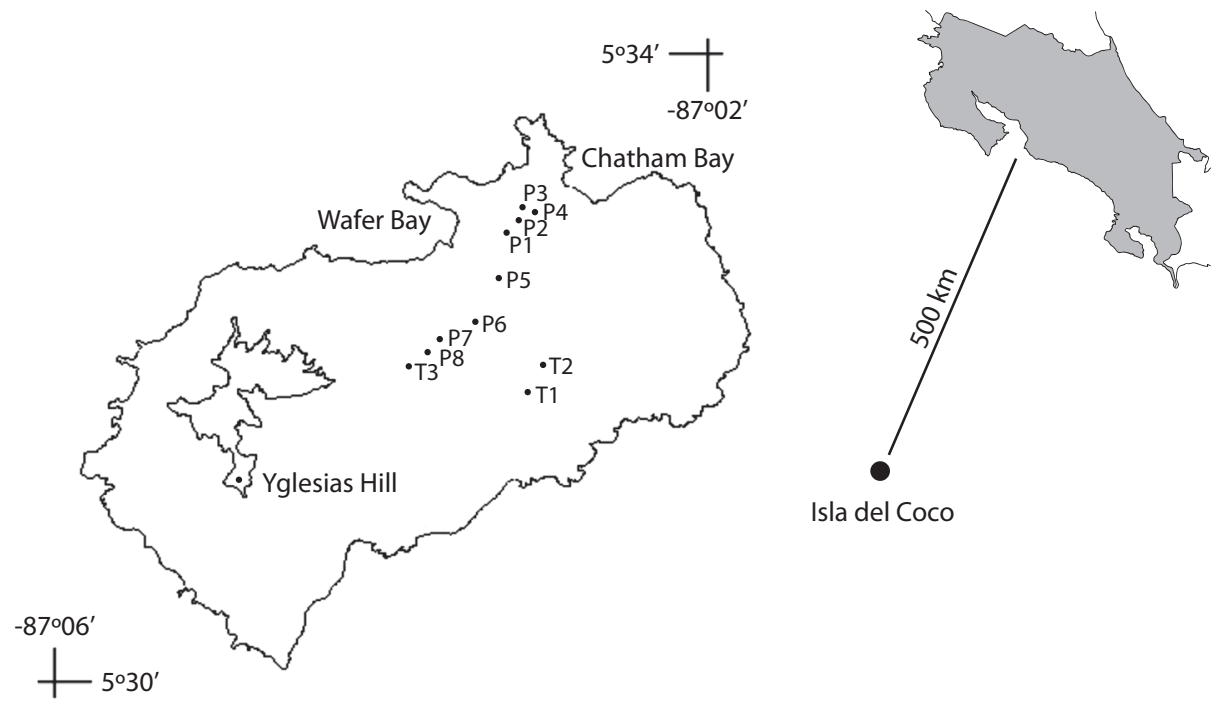

Fig. 2. Geographical location of Isla del Coco, Costa Rica, and permanent sample plots. 
Trusty et al. (2006). Isla del Coco has a rugged topography, in consequence the study sites are difficult to access. Existing trails were used for the location of PSP. Therefore, four PSP (designated as 1,2, 3 and 4) were located along the path connecting the Chatham and Wafer Bays. Then, PSP 5 was located near Wafer Bay on the trail to Genio River and PSP 6, 7 and 8 on the trail to Cerro Yglesias (Fig. 2).

Years of measurement and measured variables in PSP: Besides performing the measurements in 2006, in 2012 the PSP were re-established and measured once more, therefore, these were assessed six years after its establishment. In each PSP, all individuals with a diameter at breast height $(\mathrm{DBH}) \geq 5 \mathrm{~cm}$ were measured in diameter and total height (h). Each individual registered in the PSP was marked with a numbered aluminum tag and the DHB measurement point was marked on the trunk. (1.3m from the ground).

Regeneration: The regeneration sampling inside of PSP consisted of a subsample of $8 \%$ of the area of each PSP. In each PSP, two temporary transects of $50 \times 2 \mathrm{~m}$ were established, subdividing them on $2 \times 2 \mathrm{~m}$ grid. The transects were systematically established over the PSP central line. Regeneration sampling outside of PSP, two transects of $100 \times 2 \mathrm{~m}$ at Los Llanos de Palo de Hierro site and a one transect on the path to Cerro Yglesias were established. The transects were established to increase the sample size for regeneration analysis due to the low values observed inside the PSP (Fig. 2).

In the regeneration sampling of the species from the upper strata, seedlings $(>0.3-\leq 1.5 \mathrm{~m}$ tall) and low saplings ( $>1.5 \mathrm{~m}$ and $\leq 5 \mathrm{~cm} \mathrm{DBH})$ were identified and counted. For regeneration of $S$. holdridgei, besides the previous categories, young plants with a height lower than $30 \mathrm{~cm}$ were counted (Sánchez unpublished). For high seedlings (DBH $>5 \mathrm{~cm}$ and $\leq 10 \mathrm{~cm}$ ) measurements from the PSP were obtained. Regeneration was measured in terms of abundance $\left(N h a^{-1}\right)$.
Population status analysis The population status was analyzed by the Importance Value Index (IVI). This index represents the ecological weight of the species, based on abundance (number of individuals per PSP or per hectare and it is represented by $\mathrm{Nha}^{-1}$ ), frequency (presence of a species in the record units), and dominance (basal area in square meters) (Lamprecht, 1990). Additionally, IVI components were analyzed separately.

Basal area $\left(\mathrm{Gha}^{-1}\right)$ was determined from DBH using the following equation:

$$
\begin{gathered}
\mathrm{Gha}^{-1}=\sum 0.7854 \mathrm{~d}^{2}, \text { where } \mathrm{d} \text { is the DBH of } \\
\text { each tree. }
\end{gathered}
$$

The diameter distribution at intervals of $10 \mathrm{~cm}$ was analyzed; the abundance per diameter class corresponds to a fraction of the total abundance. The diametrical distribution of $S$. holdridgei was compared against the diametrical distribution of the forest to determine its influence upon it.

Sacoglottis holdridgei influence on forest canopy: It was determined by the number of individuals per hectare $\left(N h a^{-1}\right)$ in the three height strata of the forest. The three strata were defined following Lamprecht (1990): upper strata corresponding to trees with heights greater than $2 / 3$ of the total height, the middle strata corresponding to trees with heights between $1 / 3$ and $2 / 3$ of the total height, and low strata corresponding to trees with heights lower than $1 / 3$ of the total height.

Mortality and recruitment was determined from two measurements on the time interval $(\Delta \mathrm{t}=6)$. Two exponential growth models were used on continuous time, mortality (Nebel, Kvist, Vanclay, \& Vidaurre, 2001) and recruitment rate (Phillips, Hall, Gentry, Sawyer, \& Vasquez, 1994):

Mortality: 


$$
\begin{gathered}
R m=\frac{\ln N o-\ln (N o-N m)}{\Delta t} \\
\text { Recruitment rate: } \\
R r=\frac{\ln (N o-N m-N r)-\ln (N o-N m)}{\Delta t}
\end{gathered}
$$

Where: No is the stem number in 2006; $\mathrm{Nm}$ individuals that died and $N r$ are the individuals that was recruited during the period $\Delta t$ (6 years).

Diameter increment: is defined as the increase in diameter between two measurements in a period of time; same that is used to determine the approximate age of the trees (Lampretch, 1990). For Isla del Coco the annual increment (IPA, due to its meaning in spanish) was calculated and expressed in $\mathrm{mm}$ $\mathrm{y}^{-1}$. The IPA was used to set the transition times, which are defined as the number of years required for the species to move from one diametric class to the next.

Data analysis: As a final statistical analysis, the values obtained were extrapolated to hectares (ha), were compared between measurement years and analyzed under the criterion of confidence limits (CL) at $95 \%$ confidence level, tests of variance (TV) with the help of the $\mathrm{F}$ distribution and comparison tests of two means (TTM) using t-Student distribution. If there is not significant differences between years of measurement, only the last one is reported.

\section{RESULTS}

Importance value index (IVI): Sacoglottis holdridgei was present in all PSP. Regarding the importance value index (IVI) of each of the species, S. holdridgei shows the highest values of IVI 190.7 $\pm 21.8(\mathrm{SD}=31.5, \mathrm{n}=8)$. Average did not differ significantly between years by discretion of confidence limits $(\alpha=0.05)$ and by the mean test $(\mathrm{t}=0.0835, \alpha=0.05$;). Ocotea insularis was the second species with higher IVI $71.1 \pm 29.9(\mathrm{SD}=43.2, \mathrm{n}=8)$. The remaining 12 species showed average values below $28.6(\mathrm{SD}=39.8, \mathrm{n}=8)$. This pattern repeats itself on the abundance, basal area and distribution variables.

Abundance $\left(\mathrm{Nha}^{-1}\right)$ : With reference to abundance for forest on average, $403 \pm 83 \mathrm{Nha}^{-1}$ $(\mathrm{SD}=120.2, \mathrm{n}=8)$ was found; statistical averages are not significantly different ( $\mathrm{CL} \alpha=0.05$; TTM: $\mathrm{t}=0.5089, \alpha=0.05)$. Meanwhile, for $S$. holdridgei, on average, a $158.5 \pm 40.3 \mathrm{Nha}^{-1}$ $(\mathrm{SD}=58.2, \mathrm{n}=8)$ was found; statistical averages are not significantly different ( $\mathrm{CL} \alpha=0.05$; TTM: $\mathrm{t}=0.2568, \alpha=0.05$ ). Considering the percentage ratio between the population of $S$. holdridgei vs the forest, the species' average percentage abundance was $39.5 \%$; statistical averages did not show significant differences (CL $\alpha=0.05$; TTM: $t=0.6781, \alpha=0.05$ ).

Basal area $\left(\mathrm{Gha}^{-1}\right)$ : For forest an average of $21.4 \pm 2.8 \mathrm{~m}^{2}(\mathrm{SD}=3.97, \mathrm{n}=8)$ was found; statistical averages were not significantly different (CL $\alpha=0.05$, TTM: $\mathrm{t}=0.2499, \alpha=0.05$ ). The basal area of $S$. holdridgei accounted for an average of $72,9 \%\left(15.6 \mathrm{~m}^{2}\right)$ of the forest $(\mathrm{SD}=4.16, \mathrm{n}=8)$; statistical averages showed no significant differences (CL $\alpha=0.05$, TTM: $\mathrm{t}=0.0611, \alpha=0.05$ ).

Diameter distribution: The assessment of forest diameter distribution in the low elevation humid forest of Isla del Coco fits the inverted $J$ model. The diameter distribution of $S$. holdridgei was the closest fit to the inverted $J$ model for the forest among all species. However, it does not reach the expected population values in diameter classes $<30 \mathrm{~cm}$, therefore, their population trend is set to a descending linear model. For diameters $>60 \mathrm{~cm}$ for the forest and for $S$. holdridgei, the trend and values are the same. This condition is given by the absence of other species with diameters $>60$ $\mathrm{cm}$. Thus $S$. holdridgei is the species which reaches such diameters (Fig. 3).

The decline in abundance observed between the diameter classes $50-60 \mathrm{~cm}$ and $60-70 \mathrm{~cm}$, is statistical significant (CI: $\alpha=0.05$, TTM: 


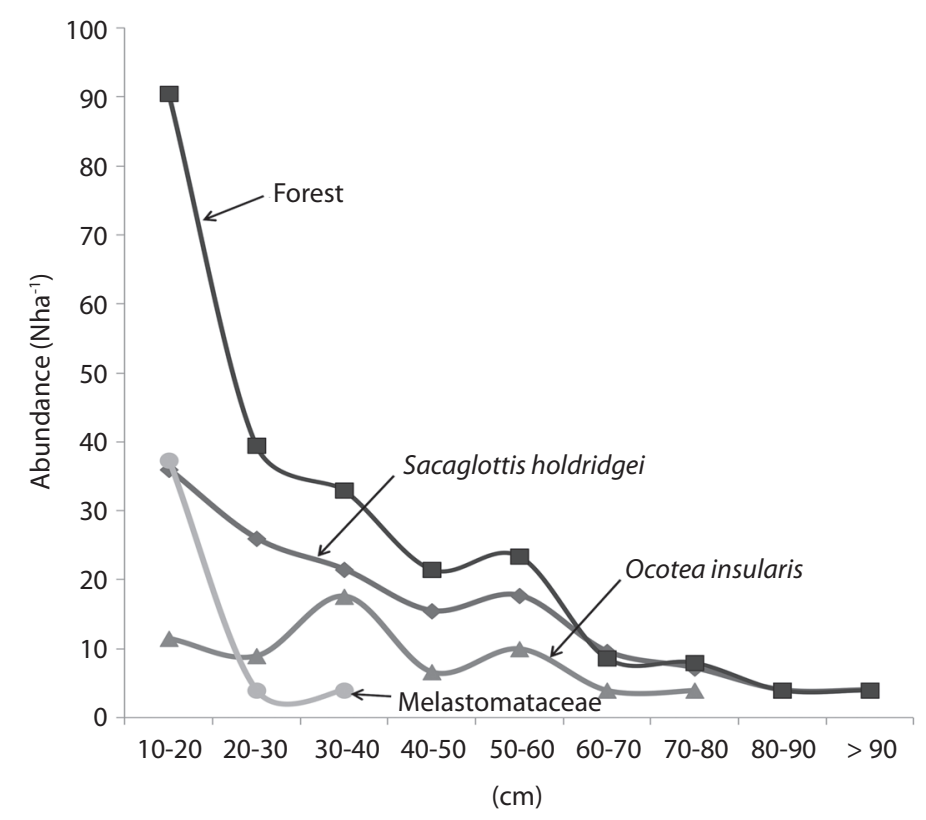

Fig. 3. Diameter distribution for the low elevation humid forest in Isla del Coco, Costa Rica, 2012.

$\mathrm{t}>2.77, \alpha=0.05)$. Decreases between diameter classes $\mathrm{DBH}>70 \mathrm{~cm}$ and $\mathrm{DBH}<100 \mathrm{~cm}$ are not significant differences (CI: $\alpha=0.05)$. Then, there is a gap in the diameter class $100-110 \mathrm{~cm}$, to complete the report of individuals in the 110$120 \mathrm{~cm}$ diameter class (Fig. 4).

Presence of the family Melastomataceae, has a great importante on the $10-20 \mathrm{~cm}$ diameter class (Fig. 3). For high saplings (DBH $>5$ $\leq 10 \mathrm{~cm}), S$. holdridgei's population did not show significant changes in abundance $\left(N h a^{-1}\right)$ in the diameter classes (CI: $\alpha=0.05$ ).

Height strata: Canopy showed no significant difference in the statistical averages of the three strata $(t=0.5545, \alpha=0.05)$. For the lower strata (36\%) and medium strata (40\%), showed higher percentages of abundance than the upper strata $(24 \%)$.

Sacoglottis holdridgei showed that on average the low, medium and upper strata contain $11.2 \%, 45.1 \%$ and $43.7 \%$ of total abundance each in 2012. The mean test showed no significant differences among measurements ( $\mathrm{t}=1.4036, \alpha=0.05)$. Comparing $S$. holdridgei and forest population, a reverse effect was observed; S. holdridgei concentrated its abundance in the upper strata while the forest abundance is accumulated in the lower strata (Fig. 5).

Regeneration: For the low elevation humid forest, on average $1518 \pm 545 \quad(\mathrm{SD}=812.78$, $\mathrm{n}=11)$ seedlings $\mathrm{ha}^{-1}, 1286 \pm 497(\mathrm{SD}=739.63$, $\mathrm{n}=11)$ low saplings $\mathrm{ha}^{-1}$ and $185 \pm 73(\mathrm{SD}=87.15$, $\mathrm{n}=8$ ) high saplings ha-1 were found (Table 1).

Species regeneration showed a different pattern compared with poles $(\mathrm{DBH}>10 \mathrm{~cm})$. Sacoglottis holdridgei frequency for seedlings and low samplings is lower than $45 \%$; in terms of abundance $S$. holdridgei lost significance passing to the first place in poles to the second in high samplings and seventh in seedlings (Table 1). Regeneration's plotted pattern showed a greater low samplings abundance, giving a polynomial distribution shape (Fig. 4).

In terms of species importance, $S$. holdridgei was displaced by Melastomataceae family (bush species with $\mathrm{DBH}<5 \mathrm{~cm}$, not included in analysis), this family had the highest abundance regeneration (Table 1). It is present in all sampling sites for seedling and low samplings; 


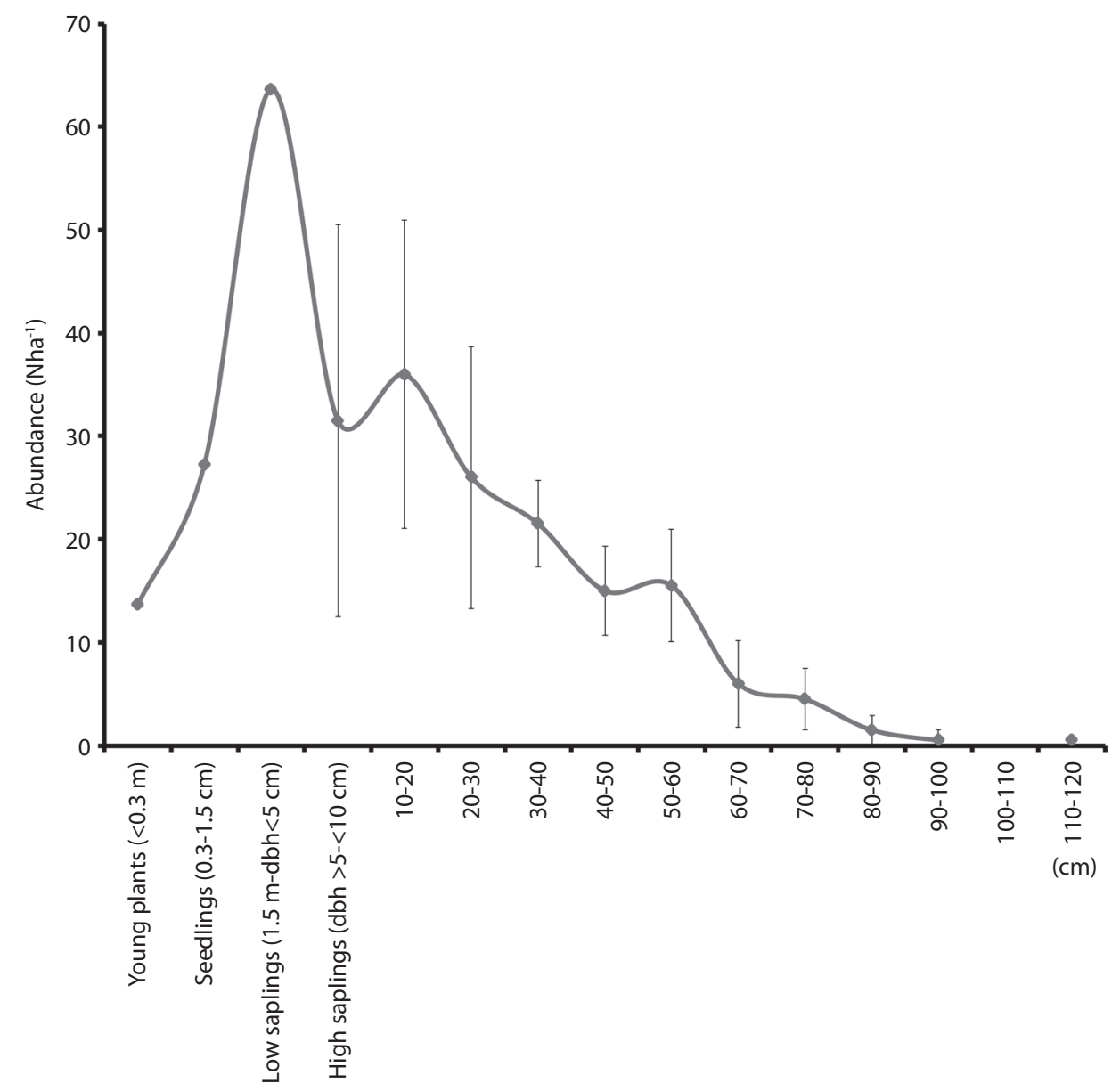

Fig. 4. Diameter distributions of population of $S$. holdridgei in the low elevation humid forest of Isla del Coco, Costa Rica, 2012.

for high samplings were found in seven of eight PSP (Table 1).

Mortality rates, recruitment and growth of S.holdridgei: The yearly mortality rate for the observed sites was $3.3 \%$ yearly, and the yearly recruitment rate of $1 \%$. The low saplings growth rate $(>5<10 \mathrm{~cm})$ is $1.045 \pm 0.307 \mathrm{mmy}-1$ $(\mathrm{SD}=1.172, \mathrm{n}=56)$.

Sacoglottis holdridgei population structure: The $S$. holdridgei population structure obtained from monitoring data and regeneration sampling, show no adjustment to the inverted $\mathrm{J}$ model due to the low values present in the first classes, young plants and seedlings (Fig. 4).

\section{DISCUSSION}

The results obtained for the IVI, diameter distribution (Fig. 3), abundance and height strata (Fig. 5) showed that S. holdridgei is the tree species with greatest importance and dominance. Dominance is clearly reflected in the medium and upper strata, which represents $49 \%$ and $72 \%$ respectively of abundance (Fig. 5). Additionally, these variables presented no significant changes among measurement, 
TABLE 1

Abundance values $\left(\mathrm{Nha}^{-1}\right)$ per PSP and average for regeneration by species groups studied in the low elevation humid forest of Isla del Coco, Costa Rica

\begin{tabular}{|c|c|c|c|}
\hline Species & AV & SD & CL \\
\hline \multicolumn{4}{|c|}{ Seedlings $(0.3 \mathrm{~m}$ to $1.5 \mathrm{~m})$} \\
\hline Forest & 1518.2 & 812.5 & 897.2 \\
\hline Melastomatacea & 727.3 & 496.7 & 293.5 \\
\hline S. holdridgei & 27.3 & 34.4 & 20.3 \\
\hline \multicolumn{4}{|c|}{ Low saplings $(1,5 \mathrm{~m}$ to $\mathrm{dbh}<5 \mathrm{~cm})$} \\
\hline Forest & 1259.1 & 730.3 & 744.1 \\
\hline Melastomatacea & 509.1 & 296.5 & 175.2 \\
\hline S. holdridgei & 63.6 & 105.1 & 62.1 \\
\hline \multicolumn{4}{|c|}{ High saplings $(\mathrm{dbh}>5 \mathrm{cmand}<10 \mathrm{~cm})$} \\
\hline Forest & 120.7 & 105.6 & 71.3 \\
\hline Melastomataceae & 66.0 & 55.2 & 38.3 \\
\hline S. holdridgei & 31.5 & 23.6 & 16.3 \\
\hline
\end{tabular}

$\mathrm{A} \mathrm{V}=$ average, $\mathrm{SD}=$ standard deviation, $\mathrm{CL}=$ confidence limit

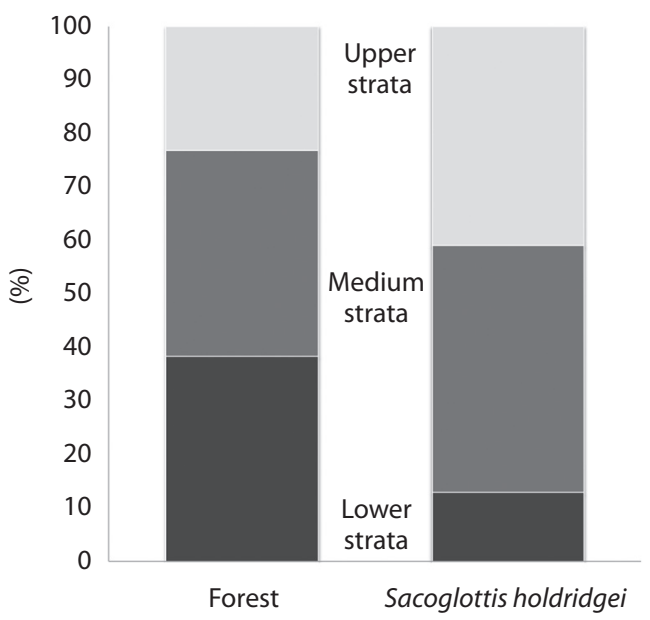

Fig. 5. Percentage values of the number of individuals per hectare $\left(N h a^{-1}\right)$ in the three height strata in the low elevation humid forest of Isla del Coco, Costa Rica, 2012.

which indicates that $S$. holdridgei $(\mathrm{DBH}>5 \mathrm{~cm})$ has sustained itself. The mortality rate of $S$. holdridgei exceeds the recorded for continental tropical forests (Nebel et al., 2001; Araujo-Murakami, Arroyo-Padilla, Killeen, \& Saldias-Paz, 2006; Ramírez, 2006; AcostaVargas, 2012) and Isla del Coco (2.99 \%) (Porras-Jiménez, 2012). The recruitment rate of $S$. holdridgei is lower than that reported for continental tropical forests (Nebel et al., 2001; Lewis et al., 2004; Araujo-Murakami et al., 2006; Ramírez, 2006; Acosta-Vargas, 2012) with Isla del Coco at $3.82 \%$ (PorrasJimenez, 2012).

The observed recruitment rate which is lower than the mortality rate for $S$. holdridgei and lower than the reported by Porras-Jiménez (2012) for the forest, clearly signals that $S$. holdridgei is not achieving its population replacement, and on its place other species are contributing to such replacement of individuals, as observed in the current regeneration.

Conversely, the regeneration sample showed that $S$. holdridgei, is absent in $54 \%$ of the sampling sites established for low saplings, seedling and young plants (Table 1) suggesting that in recent years, the species has faced problems in establishing its regeneration. Current regeneration in terms of abundance does not guarantee replacement on the diameter classes higher than $10 \mathrm{~cm}$, indicating that the species is below its regeneration capacity.

Forest regeneration data collected showed decreasing values from seedlings to high samplings (Table 1), adjusting to the inverted $J$ model and adjusting to what was observed in different continental tropical forests (Lampretch, 
1990). Stocks of regeneration and population structure suggest that there is sufficient regeneration for replacement of individuals in the forest. Also, the reported values of regeneration for Isla del Coco $\left(2805 \pm 611 \mathrm{Nha}^{-1}\right.$ with $\mathrm{DBH} \leq 5 \mathrm{~cm}$ ), were similar to those reported for Robinson Crusoe island where for $\mathrm{DBH}<5 \mathrm{~cm}$, $3147.6 \pm 59 \mathrm{Nha}^{-1}$ were reported under canopy. However, values for gap edges on Robinson Crusoe Island (7151.2 $\left.\pm 81.7 \mathrm{Nha}^{-1}\right)$ were different (Vargas, Gärtner, Hagen, \& Reif, 2013). Meanwhile, Lampretch (1990) reported an average of $72000 \mathrm{Nha}^{-1}$ for Venezuelan cloud forests seedlings (0.3-1.5 m tall) and for saplings $(1.3 \mathrm{~m}$ tall to $\mathrm{DBH}<10 \mathrm{~cm})$ reported $4900 \mathrm{Nha}^{-1}$. The lower regeneration found on Isla del Coco can be explained by the homogeneity, the appearance of predators, little ability to persist under shade, litter and soil disturbance and effects of herbivory (Lampretch, 1990; Nascimento, \& Proctor, 1997; Koda, \& Fujita, 2011).

Sacoglottis holdridgei reported low regeneration values. For this species a dominance in its regeneration was expected, as reported by Nascimento \& Proctor (1997) in forest dominated by Peltogyne gracilipes (Fabaceae), in Maracana Island, Roraima, Brazil. The regeneration pattern of $S$. holdridgei, may be related to aspects such as inbreeding, reproductive strategies, low shade tolerance, low colonization ability of gaps, seed predation, drought and displacement by introduced species.

The inverted $J$ model has been reported as an indicator of population status (Lampretch, 1990; Koda, \& Fujita, 2011). An important aspect to highlight in $S$. holdridgei is that, from the low saplings to larger diameter classes, the population curve for abundance tends to be coupled to the inverted $J$ model observed for the forest (Fig. 3), but this pattern is lost in the classes of seedlings and young plants (Fig. 4). Abundance decrease for seedlings and young plants was unexpected for S. holdridgei, especially because $S$. holdridgei represents more than $60 \%$ of individuals with $\mathrm{DBH}>15 \mathrm{~cm}$ and between $80 \%$ and $100 \%$ of the diametric classes $>50 \mathrm{~cm}$ (Fig. 3, 4), all seed producers individuals. Similarly, a lower abundance is observed for the cohort of high saplings in regard to $10-20 \mathrm{~cm}$ diameter class, this abundance decease may have originated in a period of drought, seed predation or pollination problems.

The discontinuity observed in the diametric distribution between diameter classes $50-60 \mathrm{~cm}$ and $60-70 \mathrm{~cm}$, suggests the point where the species reaches the statistical mode of larger diameters, from where it grows at very low rates or enters in a senile stage. However, there are trees that reach diameters in between $70-120 \mathrm{~cm}$. This condition may be related to the genetic, sites quality and the consequent availability of nutrients that affect the forest development (Prescott, 2002).

Decreasing in abundance and frequency of young plants and seedlings of $S$. holdridgei (Fig. 4) can be attributed to one or several hypotheses. A first hypothesis, related to the species per se in relation to the reproductive strategy, flowering, fructification, germination, genetic, and regeneration establishment. During the three visits to Isla del Coco on different dates between April to June in 2012 and 2013, it was observed that $S$. holdridgei presents simultaneous flowering and fructification events and the fruits in various stages of maturation; as well as a great quantity of fruits on the forest floor that were never observed as germinated (unpublished data,), which may suggests that the species produces fruits throughout the year. This pattern has been recorded for species of pluvial forest (Lampretch, 1990).

A second hypothesis that could analyze and explain the apparent negative effect on regeneration (young plants and seedlings) of $S$. holdridgei is the introduction of medium height animal species (Montoya, 1990; Trusty et al., 2006) such as goats (Capra hircus), cats (Felis domesticus), rats (Rattus rattus and Rattus norvegicus), pigs (Sus scrofa) and deer (Odocoileus virginianus). Although some of these animal species were introduced more than two centuries ago, the period is short to declare that the forest on Isla del Coco are adapted to their presence. According to the results obtained, 
it seems to have negative effects. The negative effects of animals in the forest are fully demonstrated. For example, deers affect regeneration by foraging limiting its development, affecting the composition, structure and successional forest development (Green et al., 1997; Gill, \& Beardall, 2001; O'Dowd et al., 2003; Rooney, \& Waller, 2003; Knight, Caswell, \& Kalisz, 2009; Takatsuki, \& Ito, 2009; Koda, \& Fujita, 2011; Shelton, Henning, Schultz, \& Clay, 2014). Also, it has been demonstrated that a preference for palatability of certain plant species exists (Takatsuki, \& Ito, 2009; Koda, \& Fujita, 2011). Similarly, it happens with pigs. They look for food in the leaf litter and soil. By removing the soil, they provoke high levels of erosion (Sierra, 2001) and at the same time, do not allow the establishment of regeneration, affecting nutrient recycling and limiting nutrient availability, necessary for regeneration establishment (Prescott, 2002).

Deer impact on the flora in Isla del Coco can be related to its introduction in 1935 (Montoya, 2004). When accepting the same low saplings regular annual increase (IPA) of $1.045 \mathrm{~mm} \mathrm{y}^{-1}$ for low saplings it is possible to estimate the age and year of germination. Thus, performing the time step analysis considering the confidence interval, the age of low saplings of $S$. holdridgei, can be estimated between 36.9 and 67.8 years with a date of establishment between 1944 and 1975; this is between 9 to 30 years after deer introduction to Isla del Coco. Therefore, low regenerating seedlings and young plants by 2012, correspond to subsequent years after 1975, where the effects by deer browsing would be expected to become visible. The abundance of regeneration of species of Melastomataceae family, signal at no effects on their regeneration by wildlife; there is evidence which relates to the effect of deer, however this does not mean that everything is attributable to their presence; research to determine the real impact of the introduced wildlife is necessary.

A third hypothesis for the low abundance of seedlings and young plants of $S$. holdridgei involves the foraging of fruits by rats, pigs and microlepidoptera larvae (Fig. 1E, F). This hypothesis is based on a "sister species", Sacoglottis gabonensis, reported as a major source of food for wildlife in Gabon (Morgan, 2009). Microlepidoptera larvae was observed in different places on the island and in different maturity stages of the fruit (unpublished data). This situation prevents the fruits to reach maturity and therefore no availability of viable seeds.

For Isla del Coco, S. holdridgei showed a mostly adult population (Figs. 3, 4, 5) with low amounts of young plants and seedlings (Table 1, Fig. 4) attributed to one or a combination of the previous hypotheses. Moreover, species of the Family Melastomataceae as H. fascicularis, Henriettea succosa and Henriettella odorata, are reported as abundant species among diameter classes 10-30 cm (Fig. 3), seedlings and saplings (Table 1). Also, these species are characterized by a high seed production, sites colonization, fast growth, and dispersion favored by birds. Homologous way, the mentioned factors have determined the development of Rubus ulmifolius (Rosaceae) and Aristotelia chilensis (Eleocarpaceae) in Robinson Crusoe Island and changed the structure and composition of the forest (Smith-Ramírez et al., 2013). This could be happening in Isla del Coco. In fact, the species of Melastomataceae have overcome in abundance of regeneration to the upper canopy species, ensuring the necessary regeneration to colonize gaps and be able to establish a new canopy of lower height and different composition, that added at least to one of the hypotheses posed, would produce a change in the current structure of the forest and the abundance of the today dominant species $S$. holdridgei.

\section{ACKNOWLEDGMENTS}

I acknowledge the project "Monitoring of forest ecosystems to strengthen conservation strategies and forest use project: a contribution to the Costa Rica Carbon Neutral initiative" funded by CONARE. To the Research Vice-rectory of the Instituto Tecnológico de Costa Rica for their support to this project and 
this publication. To the Isla del Coco Marine Conservation Area and Isla del Coco National Park and officials who gave their support and collaboration. To Roger Moya Roque for his guidance writing this paper. To Michael Antonio Porras for their solidarity and support in the field. To Fabiany Herrera and Barry Hammel for their contributions in providing information for this paper. To Fabiana Murillo for her contributions and support. Barry Hammel, Frank Ramírez, Elemer Briceño and anonymous reviewers provided valuable comments on an earlier draft of this paper.

\section{RESUMEN}

Isla del Coco es la única isla oceánica del pacífico oriental con clima tropical húmedo. Sus bosques tienen una estructura particular, un arreglo único de especies y alto endemismo. A la fecha, son pocos los estudios realizados sobre flora y monitoreo del bosque. La estructura poblacional de Sacoglottis holdridgei fue analizada utilizando datos de seis años de monitoreo entre 2006 y 2012 y un muestreó la regeneración en 2012. Sacoglottis holdridgei fue la especie arbórea de mayor importancia. En 2012 reportó el mayor Índice de Valor de Importancia (190.7 \pm 21.8$)$, mayor abundancia ( $158.5 \pm 40.3 \mathrm{Nha}-1$ o $39.5 \%$ del total) y mayor área basal (15.6m2ha-1 o $72.9 \%$ del total). Está presente en los tres estratos de altura con dominancia en el estrato alto. La mortalidad en el periodo fue del $3.3 \%$ y el reclutamiento de $1.2 \%$. La distribución diamétrica del bosque se ajusta al modelo de J invertida; de todas las especies solo $S$. holdridgei tiende a ajustarse para dap $>40 \mathrm{~cm}$. La regeneración se ajustó al modelo de J invertida y reportó valores inferiores a bosques continentales. Aún siendo la especie dominante, $S$. holdridgei reportó bajos valores de regeneración. Esta condición particular da paso a plantear hipótesis relacionadas a la introducción de especies, biología de la especie y cambio climático las cuales pueden influir en el desarrollo futuro de $S$. holdridgei y de los bosques de Isla del Coco.

Palabras clave: Isla del Coco, Sacoglottis holdridgei, regeneración, población, cambio climático, mortalidad, reclutamiento.

\section{REFERENCES}

Acosta-Vargas, L. G. (2012). Análisis silvigénico de los bosques húmedos tropicales del Parque Nacional La Cangreja. (Thesis Licenciatura). Instituto Tecnológico de Costa Rica, Cartago, Costa Rica.
Araujo-Murakami, A., Arroyo-Padilla, L., Killeen, T. J., \& Saldias-Paz, M. (2006). Dinámica del bosque, incorporación y almacenamiento de biomasa y carbono en el Parque Nacional Noel Kempff Mercado. Ecología en Bolivia, 41(1), 24-45.

Bogarín, D., Warner, J., Powell, M., \& Savolainen, V. (2011). The orchid flora of Cocos Island National Park, Puntarenas, Costa Rica. Botanical Journal of the Linnean Society, 166(1), 20-39.

Bolívar, A., Rovinski, Y., \& Ching, E. W. (2000). La pesca en la Isla del Coco. Estudio Integral para el mejoramiento del control pesquero en la zona de influencia del Área Conservación Marina y Terrestre Isla del Coco. (Informe Técnico). San José, Costa Rica: Fundación Amigos de la Isla del Coco y Área de Conservación Marina y Terrestre Isla del Coco.

Castillo, P., Batiza, R., Vanko, D., Malavassi, E., Barquero, J., \& Fernández, E. (1988). Anomalously young volcanoes on old hot-spot traces: I. Geology and petrology of Cocos Island. Geological Society of America Bulletin, 100(9), 1400-1414.

Cortés, J. (2008). Historia de la investigación marina de la Isla del Coco, Costa Rica. Revista de Biología Tropical, 56(Supplement 2), 1-18.

Cortés, J. (2012). Bibliografía sobre investigaciones marinas, oceanográficas, geológicas y atmosféricas en el Parque Nacional Isla del Coco y aguas adyacentes, Pacífico de Costa Rica. Revista de Biología Tropical, 60(Supplement 3), 363-392.

Cuatrecasas, J. (1961). A Taxonomic Revision of the Humiriaceae (Vol. 35). Washington DC: Smithsonian Press, Smithsonian Institution.

Cuatrecasas, J. (1964). Miscelánea sobre Flora Neotrópica, I. Ciencia, 23, 137-151.

Donlan, C. J., Tershy, B. R., Keitt, B. S., Wood, B., Sánchez, J. Á., Weinstein, A., ... \& Alguilar, J. L. (2000). Island conservation action in northwest Mexico. In Proceedings of the Fifth California Islands Symposium (pp. 330-338). California, USA: Santa Barbara Museum of Natural History. Recuperado de http:// bio.research.ucsc.edu/people/croll/pdf/Donlan_2000. pdf

Fosberg, R., \& Klawe, W. L. (1966). Preliminary list of plants from Cocos Island, In R. I. Bowman (Ed.), The Galápagos, (pp. 187-189). Berkeley, California: University of California Press.

Gill, R. M. A., \& Beardall, V. (2001). The impact of deer on woodlands: the effects of browsing and seed dispersal on vegetation structure and composition. Forestry, 74(3), 209-218.

Green, P. T., O’Dowd, D. J., \& Lake, P. S. (1997). Control of seedling recruitment by land crabs in rain forest on a remote oceanic island. Ecology, 78(8), 2474-2486. 
Herrera, W. (1986). Clima de Costa Rica, vol. 2. In L. D. Gómez (Ed.), Vegetación y Clima de Costa Rica. San José, Costa Rica: Editorial Universidad Estatal a Distancia (EUNED).

Knight, T. M., Caswell, H., \& Kalisz, S. (2009). Population growth rate of a common understory herb decreases non-linearly across a gradient of deer herbivory. Forest Ecology and Management, 257(3), 1095-1103.

Koda, R., \& Fujita, N. (2011). Is deer herbivory directly proportional to deer population density? Comparison of deer feeding frequencies among six forests with different deer density. Forest Ecology and Management, 262(3), 432-439.

Lamprecht, H. (1990). Silvicultura en los trópicos: los ecosistemas forestales en los bosques tropicales y sus especies arbóreas; posibilidades y métodos para un aprovechamiento sostenido. Bonn, Germany: Deutsche Gesellschaft fur Technische Zusammenarbeit (GTZ) GmbH.

Lewis, S. L., Phillips, O. L., Sheil, D., Vinceti, B., Baker, T. R., Brown, S., ... \& Vásquez Martínez, R. (2004). Tropical forest tree mortality, recruitment and turnover rates: calculation, interpretation and comparison when census intervals vary. Journal of Ecology, 92(6), 929-944.

Malavassi, E. (1983). Visita al Parque Nacional Isla del Coco. Revista Geográfica de América Central, 1(1516), 211-219.

Montoya, J. M. (1990). Plan de Manejo Parque Nacional Isla del Coco. Documento de Trabajo ver. 14. San José, Costa Rica: Sistema de Parques y Reservas Marinas (SIPAREMA), Servicio de Parque Nacionales (SPN), Ministerio de Recursos Naturales, Energia y Minas (MINEMEM)

Montoya, M. (2004). Vertebrados terrestres alóctonos de la Isla del Coco, Costa Rica. (Report). San José, Costa Rica: Fundación Amigos de la Isla del Coco y Área de Conservación Marina Isla del Coco.

Morgan, B. J. (2009). Sacoglottis gabonensis-a keystone fruit for forest elephants in the Réserve de Faune du Petit Loango, Gabon. African Journal of Ecology, 47(2), 154-163.

Nascimento, M., \& Proctor, J. (1997). Population dynamics or five tree in a monodominant Peltogyne forest and two other forest types on Maracaná Island, Roraima, Brazil. Forest Ecology and Management, 94, 115-128.

Nebel, G., Kvist, L. P., Vanclay, J. K., \& Vidaurre, H. (2001). Forest dynamics in flood plain forests in the Peruvian Amazon: effects of disturbance and implications for management. Forest Ecology and Management, 150(1), 79-92.
O’Dowd, D. J., Green, P. T., \& Lake, P. S. (2003). Invasional 'meltdown'on an oceanic island. Ecology Letters, 6(9), 812-817.

Phillips, O. L., Hall, P., Gentry, A. H., Sawyer, S. A., \& Vasquez, R. (1994). Dynamics and species richness of tropical rain forests. Proceedings of the National Academy of Sciences, USA, 91(7), 2805-2809.

Porras-Jiménez, M. A. (2012). Dinámica de los bosques del Parque Nacional Isla del Coco, Área de Conservación Marina Isla del Coco. (Thesis Licenciatura). Instituto Tecnológico de Costa Rica, Cartago, Costa Rica.

Porras-Jiménez, M. A., Acosta-Vargas, L. G., CastilloUgalde, M., \& Quesada-Monge, R. (2014). Estructura y composición florística del bosque nuboso de la Isla del Coco. Tecnología en Marcha, VI Encuentro de Investigación y Extensión 2014, 22-36.

Prescott, C. E. (2002). The influence of the forest canopy on nutrient cycling. Tree Physiology, 22(15-16), 1193-1200.

Ramírez, A. (2006). Ecología métodos de muestreo y análisis de poblaciones y comunidades. Bogotá, Colombia: Editorial Pontificia Universidad Javeriana.

Rivera, W. J. (2006). Estructura y composición del bosque premontano del Parque Nacional Isla del Coco. Área de Conservación Marina Isla del Coco. (Thesis Licenciatura). Instituto Tecnológico de Costa Rica, Cartago, Costa Rica.

Rojas, W., \& Alvarado, G. E. (2012). Marco geológico y tectónico de la Isla del Coco y la región marítima circunvecina, Costa Rica. Revista de Biología Tropical, 60(Supplement 3), 15-32.

Rooney, T. P., \& Waller, D. M. (2003). Direct and indirect effects of white-tailed deer in forest ecosystems. Forest Ecology and Management, 181(1), 165-176.

Shelton, A. L., Henning, J. A., Schultz, P., \& Clay, K. (2014). Effects of abundant white-tailed deer on vegetation, animals, mycorrhizal fungi, and soils. Forest Ecology and Management, 320, 39-49.

Sierra, C. (2001). El cerdo cimarrón (Sus scrofa, Suidae) en la Isla del Coco, Costa Rica: Escarbaduras, alteraciones al suelo y erosión. Revista de Biología Tropical, 49(3-4), 1158-1170.

Smith-Ramírez, C., Arellano, G., Hagen, E., Vargas, R., Castillo, J., \& Miranda, A. (2013). El rol de Turdus falcklandii (Aves: Passeriforme) como dispersor de plantas invasoras en el archipiélago de Juan Fernández. Revista Chilena de Historia Natural, 86(1), 33-48.

Takatsuki, S., \& Ito, T. Y. (2009). Plants and plant communities on Kinkazan Island, northern Japan, in relation to sika deer herbivory. In: D. R. McCullough, S. 
Takatsuki \& K. Kaji (Eds.), Sika Deer: Biology and Management of Native and Introduced Populations (pp. 125-143). Japan: Springer.

Trusty, J. L., Kesler, H. C., \& Delgado, G. H. (2006). Vascular flora of Isla del Coco, Costa Rica. Proceedings of the California Academy of Sciences, 57(1/11), 247.

Trusty, J. L., Tye, A., Collins, T. M., Michelangeli, F. A., Madriz, P., \& Francisco-Ortega, J. (2012). Galápagos and Cocos Islands: Geographically close, botanically distant. International Journal of Plant Sciences, 173(1), 36-53.

Vargas G. R., Gärtner, S. M., Hagen, E., \& Reif, A. (2013). Tree regeneration in the threatened forest of Robinson
Crusoe Island, Chile: The role of small-scale disturbances on microsite conditions and invasive species. Forest Ecology and Management, 307, 255-265.

Zamora, A. (2008). Estructura y composición floristica de los bosques de bahía en el Parque Nacional Isla del Coco, Área de Conservación Marina Isla del Coco. (Thesis Licenciatura). Instituto Tecnológico de Costa Rica, Cartago, Costa Rica.

Zamora, N. (2007). Humiriaceae. In B. H. Hammel, M. H. Grayun, C. Herrera \& N. Zamora (Eds.), Manual de plantas de Costa Rica, Vol. 6. Monographs in Systematic Botany from the Missouri Botanical Garden, $111,10-15$. 
